\title{
Television Unit Device
}

National Cancer Institute

\section{Source}

National Cancer Institute. Television Unit Device. NCI Thesaurus. Code C50242.

An electrical device designed to receive a television signal and display an image. 